\title{
The freshness of the fell streams: contextualizing the success of Lapin Kulta Beer in the 1960s
}

\author{
Janne Ikäheimo \\ Archaeology, University of Oulu, Oulu, Finland
}

\begin{abstract}
Purpose - As Finland became an associate member of the European Free Trade Association in early 1960s, the domestic brewing industry faced a new threat posed by imported beer. It was neutralized effectively with joint and individual efforts of the breweries. This paper aims to analyze the maneuvers taken by Tornion Olut Oy to brand its new product, Lapin Kulta, which ultimately became the most popular beer in Finland. In addition, the contemporary changes in the Finnish society with related social tensions are shown to have contributed to its success significantly.
\end{abstract}

Design/methodology/approach - Archival research focusing on primary sources complemented with biographies, historical newspaper and magazine articles as well contemporary research papers with an aim to reconstruct and better understand the historical and social context of the events.

Findings - The success of the Lapin Kulta beer in 1960s was not only based on the effective marketing, although a well-thought name, the successful participation in international beer "competitions" enhancing the brand and both improved distribution and logistics certainly contributed to it. Instead the success is shown to have depended also on seemingly odd collection of external factors. However, when put together, the success is shown to have been based on brand's capability to address the social tensions present in Finland during 1960s.

Originality/value - The importance of the context reconstruction in historical marketing research is underlined as developments traditionally attributed solely to product qualities and marketing may equally stem from a multitude of external factors. As a case study, the research represents a fresh take on the subject through a variety of previously neglected sources.

Keywords Branding history, Brewing industry, Marketing strategies, Contextualization, Northern Finland, Social tensions

Paper type Research paper

\section{Introduction}

In his widely cited treatise on cultural branding in marketing, Douglas B. Holt makes a highly accurate observation on the connection of a successful brand and its brand myth with the prevailing social tensions which it has to address acutely to become successful (Holt, 2004, p. 38, 149). Based on this premise, Holt's treatise presents a multitude of examples grounded in US marketing history with the aim of making the identification of similar cases easier in the future. While this kind of knowledge would very beneficial for the purposes of marketing (see also, da Silva Lopes, 2007, pp. 7-9), the author admits that sometimes an

(C) Janne Ikäheimo. Published by Emerald Publishing Limited. This article is published under the Creative Commons Attribution (CC BY 4.0) licence. Anyone may reproduce, distribute, translate and create derivative works of this article (for both commercial and non-commercial purposes), subject to full attribution to the original publication and authors. The full terms of this licence may be seen at http://creativecommons.org/licences/by/4.0/legalcode 
JHRM 11,2

iconic brand did not gain its dominant position through its own marketing efforts. Rather than cunning or witty marketing, societal changes and respective cultural changes might give a significant boost to the desirability of a product on its way to becoming a brand icon. According to Holt (2004, p. 156, 183), Harley Davidson motorcycles is as an illustrative example of such a brand that profited significantly from cultural texts conjured up by cultural industries that had no direct relation to the company.

In some cases, however, the contribution of cultural industries to the success of a product or a brand (for definitions, see, de Chernatony and Dall'Olmo Riley, 1998) is much less significant than the general changes occurring in society. This is especially apparent in situations where cultural texts are virtually absent and the marketing of products is either heavily regulated or banned altogether by the government executing power over corporate control (da Silva Lopes, 2007, pp. 9-12). In such cases, a brand image that manages to address an acute contradiction in society might be the most successful one (Holt, 2004, p. 149), as it has a large appeal to the masses. Still, sheer luck may also contribute significantly to the success, and a combination of both - successful branding and luck - is not completely unheard of.

To determine, which of these two components prevailed in the success of a given brand requires a deep understanding of the circumstances in which these developments have taken place. In other words, as pointed out by Fullerton (2011, p. 439) in his influential article on the application of historical methodology on marketing history studies, "The contexts of events are crucial". If the context of the events is poorly understood, or altogether ignored, the course of the events might be only partially explained. On the other hand, when viewed from an overly narrow perspective, the interpretations drawn from the source material can be skewed per se. In such cases, the importance and effectiveness of marketing efforts might be overestimated and the influence of social undercurrents on the outcome may be severely downplayed.

\section{Scope and method}

This paper presents a case study that seeks to further point out the importance of the social setting on the brand establishment by building on the ideas presented by Holt (2004) and Fullerton (2011). It focuses on a brand whose success has previously been attributed - due to limited use of sources and their one-sided interpretation - to the combined effect of efficient marketing and elevated product quality. On closer inspection, however, it turns out that the success was actually strongly influenced by a multitude of external factors. Moreover, while it seems at first that the factors thus identified do not share a common denominator with the subject of the study, their contribution and importance to the outcome becomes understandable through the reconstruction of societal tensions prevalent in the operative context at the time the product was first introduced.

In addition, the contribution focuses on an institutional environment, in which the market has traditionally been kept under a strict control of the state, and the arguments used to legitimize this governmental control are even today virtually the same than they were in the past. The production and sales of alcoholic beverages is one such segment of the market that has been historically strictly state regulated in different parts of the world (da Silva Lopes, 2007, pp. 48-49). This is especially true in Finland, a small north European country, where alcohol in its many forms has always been not only state regulated but also a much politicized and debated subject (Virtanen, 2000, p. 487), just as it is in its neighboring Scandinavian countries. This kind of claim needs to be justified here with a few words.

Until January 1, 2018, Oy Alko AB - known until 1969 as Oy Alkoholiliike AB - the state-owned alcoholic beverage retailing monopoly of Finland was the only operator in the 
country allowed to retail beer stronger than 4.7 per cent by volume, wine and spirits in its sales outlets. After a long and heated debate in the Finnish Parliament concerning the overall update of national alcohol laws (1102/2017 17 §), the upper limit for the beer allowed to be sold in grocery stores was raised to 5.5 per cent ABV. The opponents of this change, mainly the National Institute for Health and Welfare (THL), predicted that this would lead to an increase in alcohol related deaths at least by 145 cases per annum in addition to other severe consequences that would be a severe burden on national health care (Mäkelä and Österberg, 2017). As of September 2018, the first statistics on alcohol consumption after the change of legislation rather disapprove than support this view.

Nevertheless, some important alcohol-related questions, such as ordering alcoholic beverages online from other countries in the European Union, have remained unsolved, although the government has promised to update the relevant parts of alcohol legislation in the coming months (Isotalo, 2017). While the Finnish government seems to be very keen to ban the online ordering of alcoholic beverages from abroad, the supportive argumentation is currently only based on the need to preserve the state monopoly. For this reason, it has a very slim chance of approval in case any of the parties interested files a challenging case to the Court of Justice of the European Union. The reason for this is very simple: the ban contradicts the free movement of goods, which is one of the main principles of the European Union.

Yet, the current situation marks just another phase in the long and complicated history of Finland and the rest of the Europe, when it comes to the relationship of domestic and foreign alcoholic beverages. Similarly to the USA and the UK (Cabras and Bamforth, 2016; Dighe, 2016), the attitudes have varied from the times of the Prohibition Act (in force 1919-1932) to somewhat more relaxed periods. After the World War II, foreign politics and most recently European integration have forced Finland to open up its domestic markets for foreign imports (Bauters, 2007, pp. 95-112). This development had begun already in the 1960s, when in 1961 the country became an associate member of EFTA - the European Free Trade Association (Törnudd, 1969), although full membership status had to wait until 1986. Among other things, the associate membership in EFTA meant that in 1964 Finland had to open up its heavily regulated beer markets to imported strong beer (Österberg, 1974, p. 34, p. 95). As this was not exactly something the domestic brewery industry was looking for, the potential threat posed by the invasion of international beer brands resulted in determined resistance. This took place both as maneuvers taken by individual breweries and as a joint advertisement campaign organized by the Finnish Brewers' Association (fi. Panimoteollisuusyhdistys) aiming at raising the overall status of domestic beer. While the latter sub-topic has gained previous scholarly attention (Soikkeli, 2001), the involvement of individual breweries has only been sporadically touched upon in studies focusing on other themes such as beer label semiotics (Bauters, 2007).

Thus, the secondary aim of this contribution is to use a case study to characterize the production and marketing environment of beer in Finland during the 1960s. It focuses on a brewery that operated in the town of Tornio near the southwestern fringe of the administrative region of Lapland, in northern Finland. Before its closure in 2010, this brewery was for long known as Lapin Kulta Inc. thanks to its eponymous beer Lapin Kulta (en. Lapland's Gold), which was first produced in 1963 and ultimately became the most popular beer in Finland in the early 1990s. Not only has the context of this remarkable success story received surprisingly little attention, but the previous treatises on the topic have been written either by corporative executives of Lapin Kulta Inc. or various journalists. Thus, the critical marketing history truly contextualizing and explaining various factors contributing to the success of this beer has been missing. 
JHRM 11,2

Here, the operative context of the brewery has been reconstructed from a variety of sources ranging from Lapin Kulta-related articles published in newspapers and magazines to research papers and books on the history of brewing in Finland. Reports and statistics on national alcohol consumption in Finland and its repercussions have also been consulted. On the other hand, the archives of Lapin Kulta Inc., which might potentially provide deeper insight into the brewery's operations, have been explored only cursorily for a good reason. After the closure of the brewery in 2010, the archives were transferred to the National Archives of Finland, where this material has been stored since then unorganized in some 130 cardboard boxes. A superficial index of the archive contents is available online and was consulted for this article. It showed that the archive does not contain any units of apparent relevance regarding the scope of this article.

Bearing this in mind, the rest of this paper is structured as follows. First, the operational environment of Lapin Kulta is contextualized through a concise corporate history with a special emphasis on the peculiarities of Finnish alcohol legislation in the 1960s. Thereafter, the attention is turned to the establishment of Lapin Kulta as a brand, which is a multifaceted topic, not only related to the changes within the brewery or the Finnish brewing industry, but also to broader contemporary developments and trajectories in Finnish society. Finally, the observations made in previous chapters will be summarized, and their importance regarding the marketing of a brand and its historical context are assessed.

\section{Corporate history and operational environment}

The brewery that became known after 1969 as Lapin Kulta Inc. was founded by the officials and merchants of the town of Tornio already in 1873 as Torneå Bryggeri Aktiebolaget (Markkanen, 1994a, 1994b, p. 155). The early years of its operation were apparently unsuccessful, as the company went bankrupt in 1880. It was relaunched the following year as Torneå Porter- och Ölbryggeri Ab (Tornio Porter and Beer Brewery Inc.) and it continued to operate under that name until 1958. Then the name was changed to Tornion Olut Oy (Tornio Beer Inc.) as a protest to its systematically rejected applications to produce porter under a license from Oy Alkoholiliike AB (Jäntti, 2012).

In the meantime, the company had been turned into a family business (da Silva Lopes, 2007, pp. 79-81) and it was now led by master brewer Veikko Gellin, who had acquired the majority of its stocks by 1933 (Laaksonen, 1976, p. 9). After he passed away in 1945, his sonin-law Frederik Stormbom, who had married his daughter Irma already two decades earlier (Eskanen and Laalo, 1976, p. 54), took the helm in 1949. Together the couple continued Gellin's initiative to modernize the brewery and to increase its production capacity (Markkanen, 1994a, p. 4). When Frederik was unable to maintain the leadership due to an illness in 1963 that ultimately lead to his premature death five years later, his wife Irma was the natural successor for the directorship.

Since her childhood, Irma had worked at the brewery, where she had been trained by her father Veikko Gellin. In addition, she had completed a degree as a master brewer in Germany (Eskanen and Laalo, 1976; Jäntti, 2012). While characterized as a very determinate and devoted businessperson (Jäntti, 2012), Irma Stormbom probably used her position as brewery director as a psychological counterweight during the elongated period of sickness of her husband. Managing the Lapin Kulta brewery was a task she could do something about personally and that she could keep under her control. It was under her management in 1963-1964 that the brewery started its ascent towards national importance. To fully grasp the mechanisms behind this success, it is essential to present a review of the Finnish beer markets at the time. 
After the Second World War, which had temporarily halted the production of beer in Finland, the strong negative impact of the wartime was still felt by domestic brewing industry in the lack of essential ingredients and glass bottles (Österberg, 1974, p. 37; see also, Dighe, 2016, pp. 771-772). The nation sought to rebuild its operations and breweries were no exceptions to this trend. When the operational environment had finally improved sufficiently, the production of medium-strength beer (a.k.a. III-beer) containing no more than 4.7 per cent $A B V$ was begun in 1948; the production of strong beer (a.k.a. IVA-beer or export grade beer) containing max. 5.5 per cent ABV had to wait until 1953 (Österberg, 1974, p. 33). The need for the categorization of beers was primarily down to taxation, and four tax categories (I, III, IVA and IVB) for beer had been established, although these were primarily artificial creations bearing no relation to beer styles or brewing processes. While this fourtier taxation system was abolished in 1993, the tier names continue to be deeply rooted and are still used both in informal talk and by the media to reference a beer of a certain strength.

By 1955 breweries produced both III- and IVA-beers under a license given by Oy Alkoholiliike AB (Österberg, 1974, pp. 52-54) and these were sold exclusively at the stateowned Alko-stores found only in major towns and boroughs. The countryside was kept "dry" on purpose and it was noted that for men living in small villages at the time that both beer and wine were unusual alcoholic beverages (Turunen, 2002, p. 196). Also in 1955, Oy Alkoholiliike $\mathrm{AB}$ decided to regulate the beer sales further by dividing the country into marketing areas each reserved exclusively for the products of only one brewery. The only exception was made for Alko-stores in larger towns such as Helsinki and Turku, which were allowed to sell beers from two breweries (Österberg, 1974, pp. 55-56). However, the customer was able to order any beer distributed by Oy Alkoholiliike AB in Finland as a crate freight delivery to the nearest Alko-store (Turunen, 2002, p. 176). The fixed marketing areas did not only reduce the competition, but they also lead to a general unwillingness regrading product development and to a general decline in the quality of the beer brewed at the time (Österberg, 1974, p. 58). From 1953 onwards, the Finnish breweries started to receive a bonus from $\mathrm{Oy}$ Alkoholiliike $\mathrm{AB}$ if the quality of beer met certain requirements. This meant stronger competition in the following decade, when the beer market was opened up for foreign imports (Turunen, 2002, pp. 168-169). In 1962 the system was loosened up and thereafter the two biggest towns, Helsinki and Turku, were served by six breweries, while the products of three breweries were available at 23 localities (Österberg, 1974, p. 58). Finally, in 1964 the marketing area system was abolished for the distribution of strong beer (Österberg, 1974, p. 59), but Oy Alkoholiliike AB continued to dictate profit margins, retail prices and freight compensations (Turunen, 2002, p. 199).

In 1964 the Finnish beer market was divided between sixteen breweries in operation (Turunen, 2002, p. 183 Table IV), of which Tornion Olut Oy was the northernmost. The annual consumption of beer in Finland was just over 10 liters per capita, but due to somewhat loosened alcohol regulation mechanisms it rose to 19 liters by 1968 (Turunen, 2002, p. 186). After the Medium-Strength Beer Act became active in January 1969, the sale of medium-strength beer in grocery stores was allowed resulting in a hundredfold increase in sales points (Österberg, 1974, pp. 38-40). At the same time, the consumption of beer suddenly tripled (Bauters, 2007, p. 102). The subsequent growth of the breweries coincided with improvements in transportation and logistics, whereby the beer industry began to concentrate in larger breweries as smaller operators were ousted one by one from the business (Bauters, 2007, p. 99). Lagging slightly behind the first three international merger waves (see, Cabras and Bamforth, 2016, pp. 628-631; da Silva Lopes, 2002, p. 8, p. 24, 2007, pp. 129-42), the apex of corporate merging in Finnish brewing business was reached only in 1989. The beer market was thereafter divided in practice between three brewing 
JHRM 11,2

companies - Hartwall, Sinebrychoff and Olvi - that started to carry out heavy rationalization programs by closing down satellite breweries they had recently acquired (Turunen, 2002, pp. 257-8).

In October 1964, imported beers definitely entered the beverage markets of Finland (Österberg, 1974, p. 75). Their initial success was remarkable, and for a short time every fourth bottle of strong beer sold by Oy Alkoholiliike AB was an import (Österberg, 1974, Appendix 17). Initially these imports pertained to breweries located in Denmark, Switzerland, Austria and the UK, but only Danish beers brewed by Carlsberg and Tuborg were able to retain a sufficient market share (Turunen, 2002, pp. 182-187, p. 235). Although all the import taxes for beer and soft drinks shipped from the EFTA-countries to Finland were levied in 1965 (Turunen, 2002, pp. 182-187), the market share of the foreign beers had fell in 1966 into 0.5 per cent (Österberg, 1974, p. 75). Due to this negative trend, the importation of other than Danish beers to Finland ceased due to non-existent demand until 1985 (Turunen, 2002, p. 235; Bauters, 2007, p. 100). The reason for the meager success of foreign beers has been attributed, not only to their higher price by ca. 50 per cent per bottle (Österberg, 1974, p. 45) or to their similar taste profile to domestic products, but to the advertising campaign launched by the Finnish Brewers' Association in 1964.

The campaign for Finnish beer consisted of newspaper and magazine advertisements under the slogan "Finnish - of course!" (Soikkeli, 2001). These advertisements either paired domestic beer with exotic foods or its quality was praised by "foreign experts" (Soikkeli, 2001, pp. 458-459; Turunen, 2002, p. 183), most of whom happened to be foreigners working in high-profile jobs in Finland. These full-page color advertisements were geared to show the comparable quality of domestic products to the imports (Soikkeli, 2001, pp. 460-461). After the Medium-Strength Beer Act had come into effect in 1969 and Finnish breweries started to profit economically from the skyrocketing sales of medium strength beer (Mäkelä and Österberg, 1975, p. 57 Figure. 5; Karlsson and Österberg, 2010, p. 16 Figure. 2), the campaign for Finnish beer was terminated in 1970. In the following years, the marketing focused on advertising medium-strength beer in newspapers and magazines, because only soft drinks and low-strength beer could be advertised in TV commercials (Turunen, 2002, p. 213). Moreover, the content of the advertisements in any media had been regulated since 1961 by the Advertising of Alcohol Supervisory Administration. Advertisements were allowed to convey information only about the origin, production, names, types and prices of the beer as well as the modes of and the reasons for their use (Turunen, 2002, p. 213), significantly limiting possibilities regarding marketing. This is how the stage was set when Lapin Kulta was introduced in 1963-1964.

\section{From a beer to a Brand}

\section{The myths of origin behind Lapin Kulta}

As Lapin Kulta became a highly successful brand and clearly conquered the Finnish market, it makes sense to examine the origins of this beer and the story behind its name. While the sources are unanimous regarding the origin of the name, the origins of the beer itself were for some time somewhat uncertain, as two competing stories of origin had been put forward. While some sources hint at a re-branding of a beer previously produced under a different name (Markkanen, 1983, p. 10; Markkanen, 1994a, p. 4), Lapin Kulta is more often put forward as a novelty of the early 1960s (Teerijoki, 2010, p. 234). In a recent interview conducted in June 2018 (Pelttari-Heikka, 2018; see also Paljakka, 2017), the former master brewer of Lapin Kulta, Leo Andelin, describes how he developed the recipe together with his German colleague Hermann Krüger, brewery manager Irma Stormbom, reporter Esko Lumikero and restaurateur Sirkka Virkkunen. The first two people also appear in 
newspaper articles reporting the success of this beer - to be discussed in detail a little later in this paper - alongside Andelin (Tornionlaakso, 1964). The aim of this group was to develop a beer containing more esters and fruity flavors that would be easier drink than the common hoppy and heavy brews that had previously been in fashion (Pelttari-Heikka, 2018).

The name for the beer, Lapin Kulta (en. Lapland's Gold), was invented by Eugen Ulfves, the director of the advertising company Reklamainos Oy (active 1962-2005). Ulfves had a strong background in international business and had studied marketing in the USA (Kansas City) and Germany (Kiel) (Törmä, 1984, p. 28). The story is that Ulfves was spending time at his summer cottage in August in 1963, when one night he saw the golden reflection of the shining moon in the still waters of the Gulf of Finland. This event is said to have inspired him to invent the name for the beer (Markkanen, 1994a, pp. 4-5; Markkanen, 1994b, p. 157).

The name resonated cleverly with the region of its origin on a somewhat unexpected level. Finnish Lapland is the only place in Europe where in certain areas the soil of glacial origin contains mineral gold in economically utilizable quantities (Puustinen, 1991; Saarnisto et al., 1991). Thus, through its name, the beer was associated with a precious metal, a treasure that was available for the consumer to discover by purchasing the product. A somewhat amusing fact is worth mentioning in this context. When the name of the brewery was assimilated with its main product a few years later, the brewery had to first acquire a mining company from the state of Finland named Lapin Kulta Oy, founded in 1924, to make this shift possible (Pesonen, 1973; Markkanen, 1994a, pp. 5-6). Moreover, gold mining in the wilderness of Lapland was still viewed in the 1960s as a romantic and adventurous profession (Hautajärvi, 2014, p. 69), which certainly contributed to the positive image of the brand. However, as it will be soon pointed out, even more important was the association of the product with the unspoiled nature of Lapland, particularly its pristine waters.

\section{The ecstasy of gold - acquiring European recognition}

A possibility to promote this new beer opened up in mid-December 1963, when Tornion Panimo Oy received a letter from the Investigation Centre and Sales Promotion (ICSP) in Brussels. The letter was an invitation for the brewery to take part in an event called "BEER: a quality product" (Mullebrouck, 1963) and promised that every beer passing bacteriological, chemical and preservation tests was to be awarded a gold medal for its quality. Then, this award could be used for marketing purposes "since the public attaches an increasing importance to the specific value of articles available on the market". The letter also stressed out that no direct comparisons to similar products from other breweries would be carried out, thus explaining the use of the word "event" instead of "competition". To participate in the event, the brewery had to supply a case of beer for the tests in addition to a participation fee of 15,000 Belgian francs, which equals ca. 1,800 euros or 2,000 US dollars using the year 2015 as reference (www.historicalstatistics.org).

The next spring on April 10 1964, a notification letter (Mullebrouck, 1964) arrived at Tornion Olut Oy stating that the Lapin Kulta A III beer had won a gold medal for its quality: it had passed bacteriological tests and showed no haziness after being stored for a month at $+30^{\circ} \mathrm{C}$ (Verheyden, 1964). Approximately 300 beers had been sent to the event and only 32 of them had earned the prestigious Medaille d'Or de la Qualite Biere gold medal (Figure 1). At least, this was how the award was presented to the Finnish press and public a couple of weeks later (Tornionlaakso, 1964). However, Lapin Kulta was neither the only nor the first Finnish beer to receive an international award. At the same event Auran Panimo Oy received the same award for its Linna-olut AIII beer, whereas Porin Panimo had won three Monde Selection awards for its Karhu export beer between 1962-1963 in the "Beer 


\section{JHRM 11,2}

\section{Figure 1.}

Lapin Kulta A III export beer label with the Medaille d'Or de la Qualite Biere award medal received from Investigation Centre and Sales Promotion.

Reproduced by permission of $\mathrm{Oy}$ Hartwall Ab.

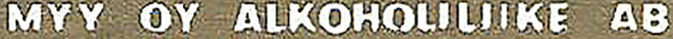

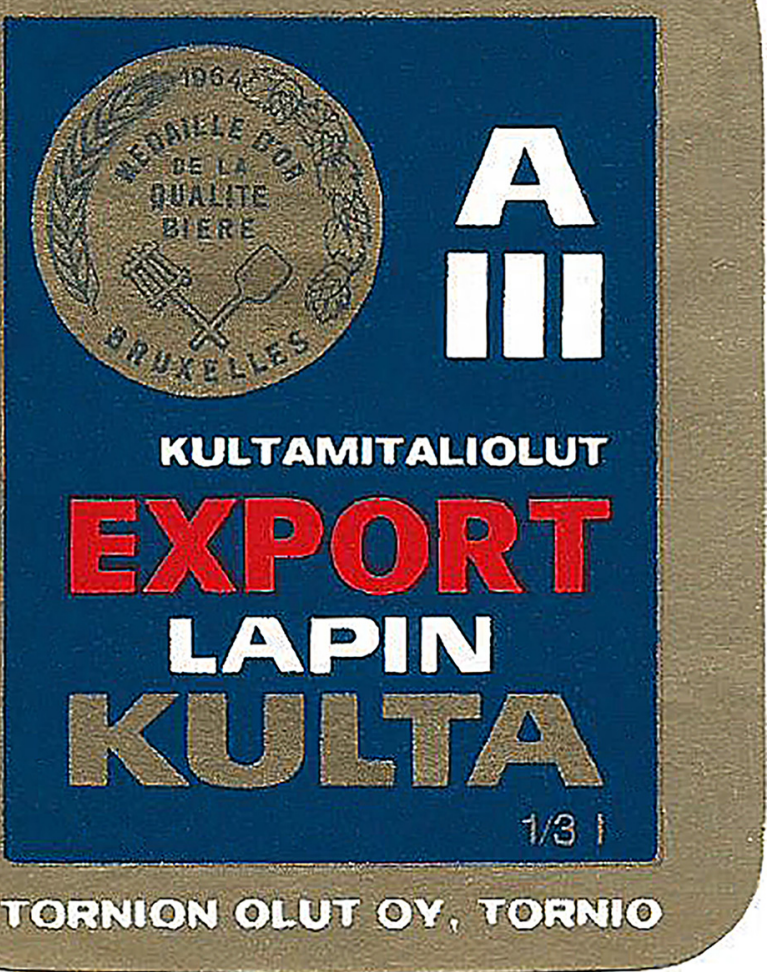

Olympics" arranged by International Quality Institute. In 1964 Tornion Olut Oy also participated in this competition with its medium-strength beer Lapin Kulta III but was awarded only a bronze medal. Fortunately, the award could also be presented as a Prix d'Honeur (Figure 2), an honorary prize that suited marketing purposes much better than the signifier of third place.

Award-winning breweries went on to print the images of the prizes they had won on their respective beer labels (Bauters, 2007, pp. 119-126). This was important for multiple reasons. First, these recognitions had been designed in the first place to promote images of tradition and quality, which is obviously a positive asset recognized today as brand heritage (Hakala et al., 2011, pp. 448-450). Secondly, these awards with associated medals were material demonstrations to domestic consumers that Finnish beers were superior rather than subpar to their European rivals (Bauters, 2007, p. 125). The success in this event was a significant in a country, where the inhabitants have for long collectively defined themselves as a "sports-crazy nation".

Reflected against this mental backdrop, the success of Lapin Kulta beer was evidently seen by the public as an extension of Finland's triumphs in the Winter Olympic Games held in Innsbruck (Austria) 29.1.-9.2.1964, in which the country had finished fourth in the medal count with ten medals (3 golds, 4 silvers and 3 bronzes). The Finnish hero of these games was Eero Mäntyranta (1937-2013), who had won an Olympic gold medal in both men's 


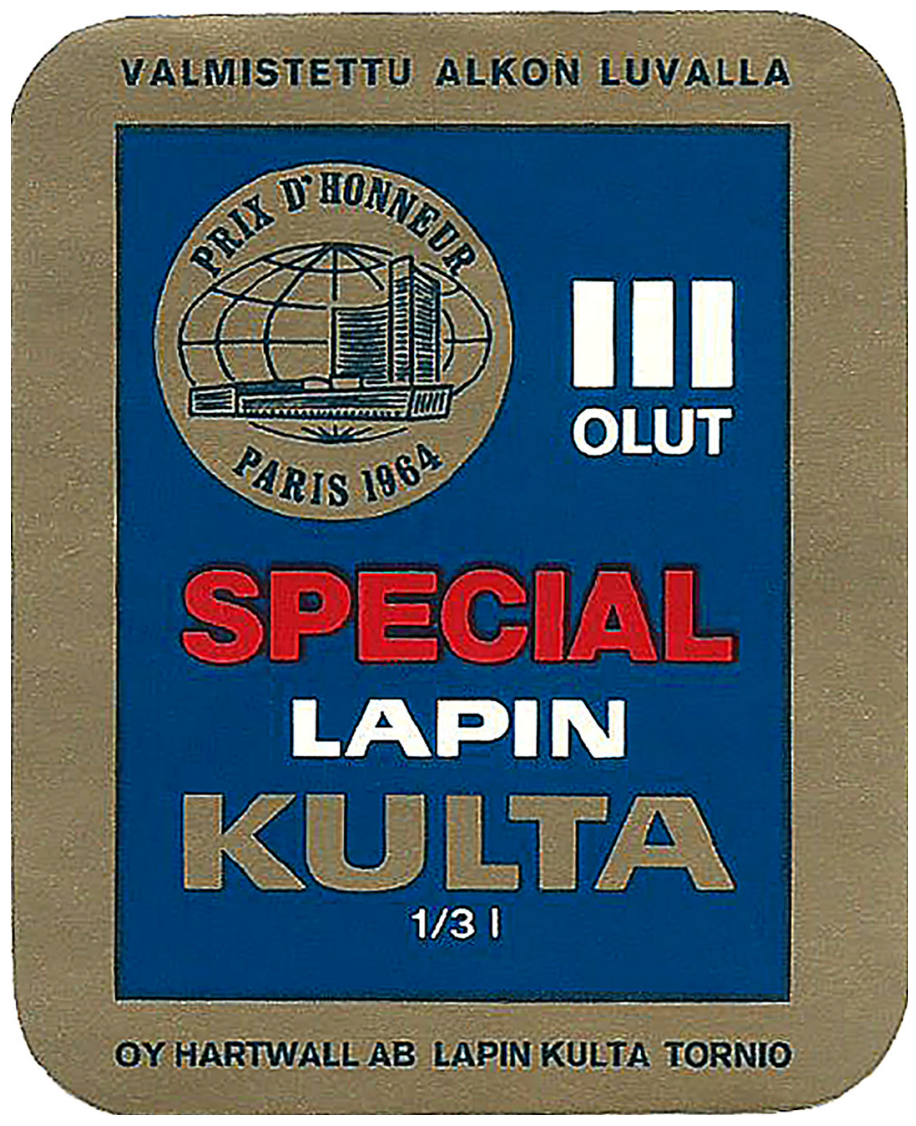

Success of Lapin Kulta Beer

Figure 2.

Lapin Kulta III special beer label with Prix d'Honeur award medal received from Monde Selection in 1964. Reproduced by permission of $\mathrm{Oy}$ Hartwall Ab

$15 \mathrm{~km}$ and $30 \mathrm{~km}$ cross-country skiing races. He was a Lappish athlete, who hailed from the village of Pello located just 120 kilometers north of Tornio. With these victories in skiing and brewing, the image regarding the province of Lapland became at least subconsciously associated with winning. Thirdly, in a country where the state regulated alcohol advertising strictly, these awards represented a way for turning remarks on the quality of beer from opinions to scientifically validated facts, thus representing an innovative way to gain more attention for the product.

Expanding the markets - Lapin Kulta goes south

In 1963, when Tornion Olut Oy started its marketing efforts with Lapin Kulta in southern Finland, the beer was first advertised with the slogan "A step ahead with the water of Lapland" (my translation). Apparently, the brewery soon found that the image of the pristine waters of Lapland was not conveyed efficiently enough this way, as the slogan was replaced with the phrase "The freshness of the fell streams to the banks of [the] Vantaa" [River] (Markkanen, 1994a, p. 5). The seemingly innocent reference to local geography caused an outrage in the south (Kuikka, 1983, p. 22), as the Vantaa River that flows into the Gulf of Finland in Helsinki was currently experiencing a serious environmental catastrophe. 
JHRM 11,2

By the early 1960s, the river had been used for long as an open drain by local industries and farmsteads, and the growing environmental awareness together with concerns regarding the local ecosystem had led to the foundation of the Water Protection Association of the River Vantaa and Helsinki Region in 1963. At the time, the pollution caused by insufficient wastewater management was also a general issue on a national level (Leino-Kaukiainen, 1999). In this somewhat sensitive situation, the advertising campaign practically rubbing salt into the wounds of its potential consumers, was not a success. For this reason, the slogan was quickly adjusted by dropping the reference to local geography. After being shortened to "The freshness of the fell streams" and backed up with corresponding generic imagery depicting the untouched nature of Lapland, the marketing formula turned out to be very successful (Niemi, 1973, p. 33).

In fact, in a later survey conducted among Finnish beer consumers about their associations concerning domestic beer brands (Laaksonen and Leminen, 1996), Lapin Kulta was the only one which did not receive any negative feedback. Instead, the association with Finnish Lapland through the brand name and the mental images it managed to evoke of unspoiled nature emerged in the survey as the two main factors explaining its positive image (Laaksonen and Leminen, 1996, pp. 37-1540, see also (de Chernatony and Dall'Olmo Riley, 1998, p. 421). Therefore, the brand is a prime example on the use of geopsychology (Gatrell et al., 2014, see also, da Silva Lopes, 2007, pp. 153-4) in beer marketing. This is particularly evident, as the success of Lapin Kulta was very likely boosted by the environmental issues described above.

In the meantime, tourism from southern Finland to Lapland had increased considerably in the early 1960s. The Finns had now longer periods of annual leave, and the members of middle and working classes were also able to purchase automobiles (the State of Finland had regulated their import until 1962) and travel for new experiences. The public image of Lapland was very attractive, as in the minds of the Finnish population it had replaced the region of Karelia, which had been conceded to the Soviet Union in 1944 as a part of the Moscow Armistice, and was viewed as an enchanted wilderness of romanticism and wanderlust (Hautajärvi, 2014, p. 200, 266, 316). Many people were introduced to Lapin Kulta beer during these visits, and this sense of novelty was exploited by the brewery in an innovative marketing scheme. A postcard reminding people about the new availability of Lapin Kulta in southern Finland was sent to every tourist from the Helsinki metropolitan area who had visited Lapland in the summer or fall of 1964. This campaign is customarily offered as an explanation of how Lapin Kulta rose to the fourth place in popularity among beers available in southern Finland within a period of two months (Markkanen, 1994a, p. 5; Markkanen, 1994b, p. 158).

While increased tourism from southern Finland to Lapland certainly contributed to general awareness of the Lapin Kulta brand, the beer also enjoyed a special status in southern Finland. Because of the elevated costs of transportation that presented a constant challenge for the brewery (Markkanen, 1994a, p. 8), Tornion Olut Oy had already teamed up with Hartwall Inc. in 1965. While Hartwall started to distribute Lapin Kulta beer in the south, Tornion Olut Oy offered its own logistical chain for the production and distribution of Hartwall's soft drinks in the north (Markkanen, 1994a, p. 6; Turunen, 2002, pp. 179-181). In addition, Oy Alkoholiliike AB, the national state alcohol monopoly had allowed Lapin Kulta to be sold at a higher price than other domestic brews to compensate for the elevated costs of transportation. The actual difference in price was not much; only 10 pennies per bottle due to the distance of transportation exceeding 500 kilometers (Österberg, 1974, p. 47), but the overall effect was more profound than just the difference. For example, due to this difference Lapin Kulta was the only beer named in bar price lists, while the rest of the domestic beer 
selection had been grouped under the generic title "other beers" (Niemi, 1973, p. 33; Kuikka, 1983, p. 25). As the average bar customer did not know the reason for the difference in price, Lapin Kulta was easily taken for a luxury brand. Also the looks of the product with foreign, but still recognizable words "export" (IVA-beer) and "special” (III-beer) printed in red on the label along with a golden medal containing inexplicable words in French may have further enhanced this image.

Moreover, Lapland was and still is quite far away both physically and mentally from southern Finland; the distance between Tornio and Helsinki is 630 kilometers as the crow flies and about a hundred kilometers more by road. This remoteness has always contributed to the image of Lapland as a strange periphery or mythical enchanted land (Hautajärvi, 2014, pp. 24-25, p. 56-60, 355; Herva, 2014, pp. 315-317) characterized by its extreme nature including the midnight sun in summer and the northern lights in winter as well as its indigenous inhabitants, the Sámi. Thus, it is perhaps no exaggeration to claim that Lapin Kulta was truly regarded as an "import beer" in the south (Bilkey and Nes, 1982). The resulting image was so strong and persistent that in an interview with the former Lapin Kulta CEO Leo "Kixi” Laaksonen, published by Suomen Kuvalehti magazine in the early 1980s (Kuikka, 1983), the author of the article characterizes the drinkers of Lapin Kulta as "better people, the consumers of a brand".

Setting the success of Lapin Kulta in the broader social context, it is also worth pointing out that not only the beer brewed in Tornio made its way from the north to the south, as the 1960s was also the decade of significant domestic migration in Finland that included both permanent and temporary elements. In the aftermath of the Second World War, people started to leave their homes in the countryside in search of a better future and to secure an income in the rapidly growing urban centers of southern Finland (Nieminen, 2007). Many found themselves in the newly built suburbs of Helsinki, where the concrete high-rise buildings and the density of inhabitants presented a drastic and mentally challenging departure from their past living conditions.

Some people, however, had to leave their homes involuntarily, as the employment policy of the Finnish government was based back then on the idea that unemployment benefits had to be earned by working wherever the labor force was needed by the state. This resulted in the creation of vast migrant construction projects in southern Finland, for which the workforce came from eastern and northern parts of the country (Nenonen, 2006). Instead of blocks of flats built of concrete, these workers were accommodated in wooden barracks and faced harsh living conditions. For both groups of migrants that were working hard to make a living, the present state of things caused feelings of rootlessness and anxiety that had to be overcome in one way or another. Many of them resorted to the bottle, and a beer bottle of a brand that was capable of producing a mental reference to things that they were forced leave behind in the move and that could potentially relieve their anxiety therefore held a certain appeal. Especially for the former inhabitants of northern Finland, who were now far away from their home regions, Lapin Kulta offered a momentary escape from the alienating environment, as one author mentions, "They did not have any other Lapland than the beer of their province" (Kuikka, 1983, p. 24).

\section{Discussion}

When the story of Lapin Kulta is projected against the interpretative backdrop coined by Holt (2004), it becomes evident that its success was not based as much on product qualities rather than social tensions and other concurrent issues the brand managed to address. Images of an unspoiled wilderness combined with slogans about pristine waters were very effective in southern Finland, where the major towns and especially their suburbs were 
JHRM 11,2

being transformed into a concrete jungle, and where the daily life was lived at a fast pace. Still, the image of Lapland as a northern Arcadia could potentially appeal to anyone living in a nation that was transforming itself from an agriculture driven society to an industrialized country. However, especially migrant workers of northern origin in southern Finland, as well as southerners who had first-hand experience of Lapland as tourists, were evidently the most important target groups of the product. The brand image spoke directly to them, as their perception of the brand was already a perfect match with their emotional needs (de Chernatony and Dall'Olmo Riley, 1998, pp. 435-436).

Against this background, it is easy to agree with Fullerton's (2011, p. 439) observation regarding the importance of event contextualization in marketing history research. It is of paramount importance for obtaining a fuller picture of the course of events. With the careful reconstruction of the context, the outcome is often remarkably more nuanced and coherent that could have been conceptualized at the outset. At the same time, the narrative concerning the event becomes customarily more complex, and this is also evident with the results of the present case study.

In the case of Lapin Kulta beer, the story of the reasons for its past success has been simplified and mythologized over the course of time. This mythologization has been partially deliberate, as the story served the marketing strategy of the product, but a significant part of it can be attributed to general lack of awareness or poor understanding of the historical context. For a nation accustomed to earning its victories through tough competition against other nations with superior resources, the idea of a gold medal award obtained in 1964 through any other way than in a frank but fierce competition was practically unimaginable. Although the representatives of the brewery had openly communicated the nature of the event in a press conference in April 1964, as the years went by, it became increasingly memorized as a competition from which Lapin Kulta beer emerged as the sole winner due to its superior product quality.

However, on closer inspection, the reason for the success of this beer seems to be practically based on other factors than its supreme quality or better taste profile. At least ten explaining factors have been be pointed out on the previous pages and some of them are worth repeating here. First, from 1963 onwards, the Stomrbom family life was centered on Frederik's severe illness, and when taking over the family business, Irma Stormbom sought to achieve miracles where she could. This pursuit received a boost from the overall development of alcohol sales regulation in 1960 s, which was quite positive from the viewpoint of domestic breweries, as quite many of the restrictions imposed after the Second World War were abolished over the course of the decade.

On the other hand, the focus of alcohol related articles in the press started to shift from the promulgation of strict teetotalism to relative moderatism emphasizing the moderate modes and ways of drinking (Piispa, 1981, pp. 176-179). A state piloted campaign attempting to redirect the consumption of alcohol from spirits to wines had begun in already 1959 (Bauters, 2007, p. 99). When the aforementioned campaign by the Finnish Brewers' Association took off in 1964, it sought to present beer as a drink fit also for other purposes than straightforward intoxication; serving aromatic cheeses with beer - a proposition which is totally outlandish even today for the average Finn - was one them (Soikkeli, 2001, pp. 457-459). The slow climb towards freedom reached an apex on January 1, 1969, when the sale of beers containing 4.7 per cent ABV or less was legalized in grocery stores.

When the success of Lapin Kulta is set against the broader developments experienced by Finnish society in 1960s, the spectrum of contributing factors is so wide that disbelief is the natural first reaction. Regional politics, vigorous rural flight, increased environmental awareness due to water pollution, integration with the rest of the Europe through the 
associate membership of EFTA, the increasing unemployment rate with associated migrant construction work projects and, finally, the success in the Winter Olympics of 1964 all had an impact on it. While many of these factors can be classified as outrightly negative in character, it is to be remembered that the 1960s was also characterized by the optimism that arose slowly during the postwar rebuilding period (Virtanen, 2000, p. 487). In 1952, the country had finally taken care of the war reparations to the Soviet Union. During the very same year, Helsinki hosted the Summer Olympic games and Ms Armi Kuusela became the first Finn to win the title of Miss Universe. The positive impact of these events lasted for long and ultimately led to the liberation of the Finnish brewing industry in 1960s (Virtanen, 2000, p. 487).

Based on previous remarks it is quite evident that the story of Lapin Kulta is quite similar to the one of Harley Davidson motorcycles (Holt, 2004, p. 156, 183). Lapin Kulta as a brand did not do much, or actually could not do much due to the state-imposed control on the marketing of alcoholic beverages, to promote the product. Instead, it was the operative context that evolved to support the myth, although the initial input of Mr Eugen Ulfves must be stressed. Both the name of the brand and the associated imagery managed to address something the resonated with the zeitgeist of mid-1960s. Indeed, in spite of initial difficulties with the marketing slogan, Lapin Kulta emerged as a brand, which was not only able to "target the most advantageous contradiction in society, but also perform the right myth, and in the right manner" (Holt, 2004, p. 63). Still, a significant amount of the success this beer had may be attributed to sheer luck, as it was launched in the right place on the right time (Holt, 2004, p. 156, 183).

The case of Lapin Kulta indicates how the context of an event often determines, or at least strongly influences, the outcome and not the other way around. However, the multivocality resulting from the use of various sources of information that enriches the emerging reconstruction of the context is only suited rarely for marketing or brand narrative generating purposes, as they are often overtly complex and unsecure constructions. Unambiguousness is the catchword of the postmodern world, and this means frequently that the information has to be simplified and the narratives regarding the past adjusted accordingly. The implications of this tendency for research into marketing history in the not so distant future are potentially profound, as scholars have to be increasingly alert and aware of the nature of their source material as well as the context in which it was created. By ignoring this aspect, critical research on marketing history will in the long run be inevitably replaced by contextless histories of marketing.

\section{Conclusions}

This contribution has addressed two issues. First, it has underlined the linkage between a successful brand and contemporary social issues it manages to address. Second, it has pointed out the importance of the context reconstruction in marketing history research through a case study focusing on a beer named Lapin Kulta and its primal steps towards unexpected popularity in Finland in the 1960s. While elevated product quality and efficient marketing have traditionally been pointed out as explaining factors for its success, the exploration of other potential contributing factors in the context of 1960s Finland raised several points. These range from government policies to increased environmental awareness and the triumphs in the 1964 Winter Olympic Games that together form a richer backdrop for the understanding of the phenomenon itself. It is further hypothesized that one of the principal challenges for the research of marketing history in the future might arise from the brand narratives created for the present postmodern consumer society, as the 
current emphasis on stories and storytelling inevitably results in tendentiously biased primary sources.

\section{References}

Bauters, M. (2007), Changes in Beer Labels and Their Meaning: A Holistic Approach to the Semiotic Process, International Semiotics Institute at Imatra, Imatra.

Bilkey, W.J. and Nes, E. (1982), "Country-of-origin effects on product evaluations", Journal of International Business Studies, Vol. 13 No. 1, pp. 89-100.

Cabras, I. and Bamforth, C. (2016), "From reviving tradition to fostering innovation and changing marketing: the evolution of micro-brewing in the UK and US, 1980-2012", Business History, Vol. 58 No. 5, pp. 625-646.

de Chernatony, L. and Dall'Olmo Riley, F. (1998), "Defining a 'brand': beyond the literature with experts' interpretations", Journal of Marketing Management, Vol. 14 No. 5, pp. 417-443.

da Silva Lopes, T. (2002), "Brands and the evolution of multinationals in alcoholic beverages", Business History, Vol. 44 No. 3, pp. 1-30.

da Silva Lopes, T. (2007), Global Brands. The Evolution of Multinationals in Alcoholic Beverages, Cambridge University Press, Cambridge.

Dighe, R.S. (2016), "A taste for temperance: how American beer got to be so bland", Business History, Vol. 58 No. 5, pp. $752-784$.

Eskanen, A. and Laalo, P. (1976), "Irma Stormbom: 'oluttehtaalla syntynyt ja oluttynnyrissä kasvanut, [Irma Stormbom Born at the Brewery, Raised in a Beer Barrel]”, Suur-Seura, Vol. 42 No. 17, pp. 52-55.

Fullerton, R.A. (2011), "Historical methodology: the perspective of a professionally trained historian turned marketer", Journal of Historical Research in Marketing, Vol. 3 No. 4, pp. 436-448.

Gatrell, J., Nemeth, D. and Yeager, C. (2014), "Sweetwater, mountain springs, and great lakes: a hydrogeography of beer brands", in Patterson, M. and Hoalst-Pullen, N. (Eds), The Geography of Beer, Springer, Dordrecht.

Hakala, U., Lätti, S. and Sandberg, B. (2011), “Operationalising brand heritage and cultural heritage", Journal of Product and Brand Management, Vol. 20 No. 6, pp. 447-456.

Hautajärvi, H. (2014), “Autiotuvista lomakaupunkeihin. Lapin matkailun arkkitehtuurihistoria [From Unlocked Cabins in the Wilderness to Vacation Cities. The Architectural History of Lapland Tourism]”, Aalto-yliopisto, Helsinki.

Herva, V.-P. (2014), "Haunting heritage in an enchanted land: magic, materiality and second world war German material heritage in Finnish Lapland”, Journal of Contemporary Archaeology, Vol. 1 No. 2, pp. 297-321.

Holt, D.B. (2004), How Brands Become Icons. The Principles of Cultural Branding, Harvard Business School Press, Boston (MA).

Isotalo, M. (2017), "Etämyyntiä rajoitetaan ja alkon monopoliasema turvataan [Distance Selling will be Regulated and the Monopoly of Alko Secured]", available at: www.ksml.fi/kotimaa/Saarikko-Et $\% \mathrm{C} 3 \% \mathrm{~A} 4$ myynti\%C3\%A4-rajoitetaan-ja-Alkon-monopoliasema-turvataan/1083524 (accessed 10 February 2018).

Jäntti, V. (2012), “Teollisuusneuvos Irma Stormbom (1917-1985) [industry counselor Irma Stormbom (1917-1985)]", available at: https://kansallisbiografia.fi/talousvaikuttajat/henkilo/1359 (accessed 10 February 2018).

Karlsson, T. and Österberg, E. (2010), “Mitä tilastot kertovat suomalaisten alkoholinkäytöstä?” [What Do Statistics Say about the Alcohol Consumption of the Finns?]”, in Mäkelä, P., Mustonen, H. and Tigerstedt, C. (Eds), Suomi Juo: suomalaisten Alkoholinkäyttö ja Sen Muutokset 1968-2008, Terveyden ja hyvinvoinnin laitos (THL), Helsinki, pp. 13-26. 
Kuikka, J. (1983), "Patruuna ei osu harhaan [A Patron Who Does Not Miss], Suomen Kuvalehti, Vol. 67 No. 44 , pp. $22-25$.

Laaksonen, L. (1976), “Torniolaisen panimoteollisuuden uranuurtajan Weikko Gellinin syntymästä 100 vuotta [A Hundred Years from the Birth of Weikko Gellin, the Pioneer of the Brewing Industry in Tornio]", Jälkikäymiset: Lapin Kulta Oy:n Sisäinen Tiedotuslehti, Vol. 1976 No. 4, pp. 6-10.

Laaksonen, P. and Leminen, A. (1996), Oluen merkitysmaailma: Kvalitatiivinen analyysi olutmerkkien mielikuvista [The Semiotic World of Beer: A Qualitative Analysis on Beer Brand Associations], University of Vaasa, Vaasa.

Leino-Kaukiainen, P. (1999), "Vesistöistä viemäreiksi: vesiensuojelu Suomessa 1945-1970 [From Water Systems to Sewers: Water Protection in Finland 1945-1970]', in Laakkonen, S., Laurila, S. and Rahikainen, M. (Eds), Harmaat Aallot: ympäristönsuojelun Tulo Suomeen, Suomen historiallinen seura, Helsinki, pp. 33-67.

Mäkelä, K. and Österberg, E. (1975), “Alkoholinkulutus ja alkoholipolitiikka Suomessa ja Ruotsissa vuosina 1951-1973. 1 [The Consumption of Alcohol and Alcohol Politics in Finland and Sweden 1951-1973. 1]", Alkoholipolitiikka, Vol. 40 Nos. 2/3, pp. 53-60.

Mäkelä, P. and Österberg, E. (2017), "Miten hallituspuolueiden tekemät alkoholilain uudistuksen linjaukset vaikuttavat alkoholin kulutukseen ja kansanterveyteen?" [How Does the Update of Alcohol Laws by Governmental Parties Affect the Consumption of Alcohol and Public Health]", available at: www.thl. fi/fi/web/alkoholi-tupakka-ja-riippuvuudet/alkoholi/usein-kysytyt-kysymykset/politiikka/mitenhallituspuolueiden-tekemat-alkoholilain-uudistuksen-linjaukset-vaikuttavat-alkoholin-kulutukseen-jakansanterveyteen-. (accessed 10 February 2018).

Markkanen, E. (1983), "Lapin kulta 110 vuotta [Lapin Kulta 110 years]”, Jälkikäymiset: Lapin Kulta Oy: n Sisäinen Tiedotuslehti, Vol. 1983 No. 4, pp. 6-19.

Markkanen, E. (1994a), "Lapin kulta 120 vuotta [Lapin Kulta 120 Years]”, Jälkikäymiset: Lapin Kulta Oy:n Sisäinen Tiedotuslehti, Vol. 1994 No. 1, pp. 3-8.

Markkanen, E. (1994b), "Lapin kulta - läänin vanhin teollisuuslaitos [Lapin Kulta - the Oldest Factory in the Province]", Tornionlaakson Vuosikirja, Vol. 1994, pp. 155-160.

Mullebrouck, R. (1963), Untitled Invitation Letter Dated 15.12.1963, Lapin Kulta Oy Archives, Box 8, The National Archives of Finland, Oulu.

Mullebrouck, R. (1964), Untitled Award Notification Letter Dated 10.4.1964, Lapin Kulta Oy Archives, Box 8, The National Archives of Finland, Oulu.

Nenonen, M. (2006), "Lapiolinjalla: Työttömät pakkotöissä 1948-1971 [The Way of a Shovel: Unemployed as Forced Labor 1948-1971]“, Jyväskylä, Atena.

Niemi, R. (1973), "Lapin olut on tullut etelään [The Beer of Lapland Has Arrived in the South]", Talouselämä, Vol. 30 No. 24, pp. 32-35.

Nieminen, M. (2007), "Population development in independent Finland: greying baby boomers", available at: www.stat.fi/tup/suomi90/joulukuu_en.html (accessed 10 February 2018).

Österberg, E. (1974), “Alkon panimopolitiikka vuosina 1948-1972 [The Brewery Politics of Alko 1948-1972]”, Alkoholipolïttisen Tutkimuslaitoksen Tutkimusseloste 79, Alkoholipoliittinen tutkimuslaitos, Helsinki.

Paljakka, E. (2017), "Palkittu klassikko-olut tekee paluun: sama panimomestari kuin yli 50 vuotta sitten [The Award-winning Beer Classic Returns with the Same Master Brewer as Over 50 Years Ago]”, available at: www.iltalehti.fi/pippuri/201706122200202244_ah.shtml (accessed 10 February 2018).

Pelttari-Heikka, S. (2018), "Rakkaudesta olueen [For the Love of Beer]", Kaleva, 13 June, p. 39.

Pesonen, M. (1973), Lapin Kulta 100 Vuotta 1873-1973 [Lapin Kulta 100 Years 1873-1973], Lapin Kulta Oy, Oulu.

Piispa, M. (1981), "Suomen sanomalehdistön alkoholikirjoittelun linjat 1951-1978 [Alcohol-related Topics in the Finnish Press 1951-1978]", Alkoholipolitiikka, Vol. 46, pp. 174-183. 
JHRM 11,2

Puustinen, K. (1991), “Gold deposits of Finland”, Journal of Geochemical Exploration, Vol. 39 No. 3, pp. $255-272$.

Saarnisto, M., Tamminen, E. and Vaasjoki, M. (1991), "Gold in bedrock and glacial deposits in the Ivalojoki area, Finnish Lapland”, Journal of Geochemical Exploration, Vol. 39 No. 3, pp. 303-322.

Soikkeli, M. (2001), "Kampanja suomalaisen oluen puolesta [The Campaign for Finnish Beer]", Yhteiskuntapolitïkka, Vol. 66 No. 5, pp. 457-462.

Teerijoki, I. (2010), "Tornion historia 3, 1918-2000 [The History of Tornio 3, 1918-2000]", Tornion kaupunki, Tornio.

Törmä, T. (1984), "Reklama festivo: faktoja ja fiktioita Reklan vuosikymmeniltä", [Reklama Festivo: Facts and Fiction from the Decades of Rekla], Reklamainos, Helsinki.

Tornionlaakso (1964), Torniolainen kultamitali esiteltiin julkiselle sanalle [The Gold Medal of Tornio was Introduced to the Press], 30 April, p. 1.

Törnudd, K. (1969), "Finland and economic integration in Europe", Cooperation and Conflict, Vol. 4 No. 1, pp. 63-72.

Turunen, M. (2002), Jos Täytätte Mun Lasini: Suomalaisen Panimo- ja Virvoitusjuomateollisuuden Vuosisata [The Century of the Finnish Brewing and Soft Drinks Industry], Panimo- ja virvoitusjuomateollisuusliitto, Helsinki.

Verheyden, F. (1964), "Rapport d'analyse", Analysis Report Dated 9.4.1964, Lapin Kulta Oy Archives, Box 8, The National Archives of Finland, Oulu.

Virtanen, M. (2000), “Alkoholikysymyksen kuolemasta [The Death of a Question regarding Alcohol]”, Yhteiskuntapolitïkka, Vol. 65 No. 6, pp. 487-488.

\section{Further reading}

Boutlis, P. (2000), "A theory of postmodern advertising", International Journal of Advertising, Vol. 19 No. 1, pp. 3-23.

\section{Corresponding author}

Janne Ikäheimo can be contacted at: janne.ikaheimo@oulu.fi

For instructions on how to order reprints of this article, please visit our website: 